\title{
The Revitalization Of Values Sahala Harajaon In Development Strategy Of Sustainable Tourism Management At Samosir Regency North Sumatera
}

\author{
Muhammad Pujiono, Budi Agusto, Farid Aulia \\ Faculty of Culture, University of Sumatera Utara, Indonesia, \\ Faculty of Law, university-Azhar Medan, Indonesia \\ Medan, Indonesia \\ Telephone number: +62618223530 \\ Email: mpoejiono@yahoo.co.id
}

\begin{abstract}
The values culture of Sahala Harajaon has been transforming,so the Sahala Harajaon (the esteem of leadership) has metamorphosed to the more acculturative. One of the results of culture acculturative is the human activities to sustain the management of tourism area. This study aims to identify the position of Sahala Harajaon in the social living of Batak Toba at Toba Samosir and to analyze the position and the participation of Sahala Harajaon in Batak Toba community at Toba Samosir Regency to the sustainable management of Danau Toba tourism area in nowadays context. The management of Danau Toba tourism area must be a part of the local community development that living on Danau Toba area. It becomes the main element to do the sustainable development. The beautiful views and all of the natural resources and human resources at Danau Toba area have been threated because of development pressure that was no kind of the social culture values in Batak Toba community. This study used qualitative method to identify and to analyze the position of Sahala Harajaon at the culture area management.
\end{abstract}

Keywords: culture values; sahala harajao; Batak toba cultur, sustainable tourism management at lake toba

\section{INTRODUCTION}

The management of tourism area must integrate the growth of tourism to the economic development programme, physics and social culture. The government participation in stimulating the tourism are: to get the infrastructure ready, even physics or non physics), to get some facilities, coordination between the government and private sector, the regulation and general promotion to national and international. The tourism sector gave the giant effects to the people, especially the local community that located at tourism area. So that, the probability to explore the culture values of Danau Toba tourism area management becomes the most important thing.

The culture values that used as a guide was the same as the majority tribe that living on Danau Toba area. That was Batak Toba tribe with Batak Toba values that became the guiding of the people who lived at Samosir Island. In Batak Toba tradition, the management area was not separated from the majesty and the leadership that manifested to "Sahala Harajaon" concept (the esteem of leadership). "Sahala Harajaon" as the life philosophy of each Batak person and could get if richness (hamoraon), esteem (hasangapon), and having many children (hagabeon) have become the part of social living in Batak Toba community.
"Sahala Harajaon" now slowly disappeared, because of modernization, that formed the culture values nowadays. The culture values had become transformed, so the "Sahala Harajaon" (the esteemed leadership) had metamorphosed to the acculturative formation. The human activities gave the effects to sustain the tourism area management. Now the government only used the existing infrastructure to solve the stagnation of the Danau Toba tourism area. But, the result was still unsignificant to push the amount of tourist, although Toba Samosir Regency was close to beautiful views of Danau Toba give probability to be the world tourism destination.

The beautiful scenery and natural resources and human resources at Danau Toba area has been lost the function because of development pressure that not at the cultural values side. This condition pushed to do the tourism area management through the study of values "Sahala Harajaon" culture to the Batak Toba community. It needs the efforts to push the "Sahala Harajaon" at Batak Toba community as culture values to making a public decision about sustainability tourism management.

\section{MATERIAL AND METHODS}

The research model that used in this research is qualitative approach. The qualitative approach has concentrate to process, so that the 
tracers of datas and information would do to know and understanding completely about "sahala harajaon" through the sustainable tourism area management. To emphasize the essence of the qualitative method in community view (emic view), so that the datas was truly true (Moleong,2000).

The datas that would be collected came from two sources: primary datas and secondary datas. The primary datas get from depth interview and participant observation that aim to get information about "sahala harajaon", and be sharped by focus group discussion. The FGD used for getting a strategy to revitalize the values of "sahala harajaon" in Batak Toba community that more applicative to develop in community empowerment widely. It can do with local condition. Another instruments are camera and tape recorder that useful to avoid the missing data and to document the situation at Danau Toba area community. The researcher has developed rapport. It could decrease the distance and the suspicious that could disturb the interview (Bungin, 2007).

The location of research was at Samosir Regency. It has the Batak Toba tribe. So, the "sahala harajaon" still urgent for the people that live at Toba Samosir Regency. The location of research was made purposively: Samosir community that has so many potentials of "sahala harajaon".

\section{RESULT AND DISCUSSION}

\section{A. Sahala Harajaon Tradition}

The social rules of Batak Toba community that integrated with power values and leadership that manifested by leadership culture "sahala harajaon". The leader must have the "sahala harajaon" (the esteem of leadership). So he could manage the needs of all Batak Toba community that need the leadership figure. "Sahala harajaon" as the life philosophy of each Batak person and could get if richness (hamoraon), esteem (hasangapon), and having many children (hagabeon) have become the part of social living in Batak Toba community. This concept was the sacral part of Batak Toba community. The information that collected from some sources shows that the getting of "sahala harajaon" to someone was the manifest from the position and powerful of the king at the traditional kingdom of Batak Toba. Once upon a time, the Batak Toba community has been knowing as cosmo-religion that believe a king was a representation of god. So, the position and the power of the king was very holy and sacral (Silalahi, 2012).

Based on cosmo-religion belief, the traditional Batak Toba community was very obeyed to the king to get the luckiness. The position of the king as the representation of god, so it was not the patron-client relationship between the king and the community. The traditional Batak Toba community belief that people have the god right, just like powerful. The voice of king was the voice of god. The king has the power from god to arrange the people life. The power was sourced from the traditional power and charismatic that pointed by dropped to "sahala harajaon" (esteem leadership) that came from god (Silalahi, 2012).

Sahala harajaon was not manifest from god, but appeared to be godfather's spirit that phenomenal at someone that potent to see "tondi" or spirit in Batak language. Tondi accompanies people in their life. If someone has been sick, tondi leave him until he is well. When someone dies, tondi will leave the body forever and will be "tondi ni na mate" (the spirit of die people) (Simaremare, 2008).

The majesty talent that came from god was a "tondi" from god. When we talk about religion, the esteem of the leader comes from "tondi" from his godfather. A king must have charisma. It takes until his grandson and so on. But as time flies, it starts to disappear and rarely be found. Only the "winner" that been given this "sahala harajaon". The power of the leader in arranging the people life was one of important aspect at social life. The city life that showed the modern life, made they have the strength rules that made and rolled by country laws. The village community that fulfilled with cultural values, was believed in culture leader to arrange the community living.

The local community was still believing in people that have "sahala harajaon" was a trusted leader. Sahala as a thing that could be reached physically. People believe that sahala as a giveness. The giveness was accompanied by "tondi" and was a sacral thing. Through "tondi", the charisma of the leader was shining. Batak Toba community at Toba Samosir Regency was still fulfilled with culture and tradition. So, the function of the culture leader was so important in their community group. The culture leader was trusted in problem solved familiarly without country laws. The charismatic figure was very important and very needed to solve the cultural and social life problem. 
The charisma of the leader was a part of "sahala harajaon" it self. The leader that has "sahala harajaon" must be smart, polite and justice in making a decision. They could make him trusted by his community. This position was representation of "tondi" or spirit that this community believes as something that physically gives to someone that has "sahala harajaon".

\section{B. Position and Function "Sahala Harajaon" to Batak Toba Community at Samosir Regency to Tourism Area Management in Nowadays}

The tourism development and promotion, at the national level or regional level, were more important to support the national development. So that, the natural richness and cultural that owned by Indonesia was needed to protect and needed the effort to conserve to be the tourism magnet to pull the amount of tourist visit even domestic or international. If the richness of culture has managed well, the tourism sector could be the leading sector that making money for this country.

The culture and local wisdom were one of the choices of cultural strategy to minimize the global effect and being the cultural mass domination that led by developed countries and has big hegemony of freethinking and "the culture" of developing countries community. One of the pull factors of culture and local wisdom as a develop based on globalization era could see from a cultural strategy perspective, increase the effect of globalization has been reducted some national cultural values. Local culture has potention and function as a counter culture to culture global domination that as a mitos of something that could not be denied (Fakih, 2003).

The local culture could be the source of local wisdom, as a source of critical to globalization. This thing happened in homogenous community. The style at globalisation and modernity, more strength in community dependency to depth values as religion, arts and literate. As the world growth homogenously, as globalization effects, the people more appreciate the inner tradition.

When we talk about tourism, every Batak people is King (Anak Ni Raja). The concept of the king was serving not be served. But to develop tourism sector, the connection of Dalihan Natolu concept to tourism aspect. Somba Marhula-hula (be polite to wife family), Elek Marboru (to protect women), Manat Mardongan Tubu (be careful to family). A king with that concept has been serving not be served. For example: when there is a domestic tourist come to the tourism area, Batak community as a king must serve the tourists. Because the Batak people think that the guests as a Raja Ni Hula-hula and they as Raja Ni Boru. The concept of Dalihan Natolu must in the mind set of Toba people. To serve a king, Raja Ni Boru was still a king. Not a servant, although he served Raja $\mathrm{Ni}$ Hula Hula. Raja Ni Boru dan Raja Ni Hula Hula only the star that once a time can change, upon the situation and condition.

\section{CONCLUSION}

1. Local wisdom in Sahala Harajaon to manage the Danau Toba tourism area could be replicated as a part of the social function of Dalihan Natolu that changed partly. Everyone has a social function. Somba Marhula-hula (being polite with the wife's family), Elek Marboru (to protect women), Manat Mardongan Tubu (being careful to family). The King must have the serving manner.

2. Sahala Harajaon was very potential to be used as the sticky of cooperation values, believing, open mind between the community. The values of Sahala Harajaon could be used to build a character the Toba community became better for the future to keep the conservation of tourism area at Toba Samosir.

3. The form of Sahala Harajaon was getting from the living experience of culture community at Danau Toba area, and the adaptation achievement that was done by the community at Samosir Regency to survive when the change of cultural simultaneously brought by an outsider or individually through some conservation action and empowerment that doing partially or collectively.

4. The connectivity of Tradition Sahala Harajaon as a part of reproduction process and art modify that be introduced through the creation of social wisdom that more adaptive to the environment condition that exists.

\section{REFERENCES}

Burhan B, "Qualitative Research", Jakarta : Prenada Media Group, 2007.

Coleman. J, "Social Capital in the Creation of Human Capital”, American Journal of Sociology 94 (Supplement), 1988, pp. 95-120. 
Fakih, M, "The Collapse of Development Theory and Globalization"., Jakarta: LP3ES, 2003.

Moleong, L. J. 2000. "Qualitative Research Methodology" Bandung: PT. Remaja Rosdakarya.

Silalahi, U. 2012. "The Position and Power of Kings in The Traditional Kingdom of One
Community in North Sumatera: Batak Toba Community". Research Report-Humanities and Social Science. Vol. 2, pp. 54-64.

Simaremare, J. 2008. Sahala dan Tondi. http://johnysimaremare.blogspot.co.id/2008/12/sahalatondi.html? $\mathrm{m}=1$ 